\title{
THE MAIN CHARACTER INNER CONFLICT ELEMENT IN DRAMA MANUSCRIPT NYANYIAN ANGSA CREATION BY ANTON CHEKOV AND THE IMPLICATIONS TOWARD LITERATURE TEACHING
}

\author{
Yogi Purnama \\ Universitas Indraprasta PGRI \\ Kartono \\ Universitas Indraprasta PGRI \\ Sohibul Anwar \\ Universitas Indraprasta PGRI \\ Jl. Nangka No. 58C Tanjung Barat, Jagakarsa, Jakarta Selatan, Kode Pos, Indonesia \\ e-mail: Yogi.purnama@unindra.ac.id
}

\begin{abstract}
The inner conflict element which happen to main character in the drama script nyanyian angsa creation by Anton Chekov. The research method which using for analysis the script is qualitative method that description analysis. Research focus internal conflict element in drama script nyanyian angsa creation by Anton Chekov with subject focus element Id $><$ Ego, Id $><$ Eros and Superego $><$ Thanatos. The research instruments analyze scene that have an element of inner conflict in the script nyanyian angsa creation by Anton Chekov. To get the results the writer using presentation table from the element of inner conflict that accumulated. The impact of implications for students, the students must be directly involved actively in literary learning activities that is drama script in the school. The student also required to understand the contents of the drama script very well. To improve literature learning that is drama script, students must improve own learning method outside of school hours, for example be part of theatre extracurricular activities. This is intended so that the ability of students can be channel properly.
\end{abstract}

Key words: inner conflict, drama script, literature teaching.

Article History: Received: 04/04/2020; Revised: 19/05/2020; Accepted: 07/06/2020; Published: 16/07/2020

How to Cite (MLA $7^{\text {th }}$ ): Purnama, Yogi, Kartono, Sohibul Anwar,. "unsur konflik batin tokoh utama dalam naskah drama nyanyian angsa karya Anton Chekov dan implikasinya tehadap pengajaran sastra." Hortatori Jurnal Pendidikan Bahasa dan Sastra Indonesia vol.4 no.2 (2020): 73-85. Print/Online. Copyrights Holder: Yogi Purnama, Sohibul Anwar, Kartono. First Publication: Hortatori Jurnal Pendidikan Bahasa dan Sastra Indonesia (2020).

\section{Pendahuluan / Introductions (12pt)}

Dalam sebuah naskah drama kebradaan tokoh sangatlah penting dalam proses penyampaian pesan yang ingin disampaikan pada sebuah karya sastra (Permata Yanda), dalam sebuah cerita pengarang selalu menghadirkan konflik dari akar permasalahan yang ingin diangkat sebagai bahan ide dan gagasan dalam sebuah cerita, pengangkatan konflik dalam cerita haruslah dikemas dengan bagik karena kekuatan dari sebuah cerita dilihat bagaimana cara pengarang menghadirkan konflik dengan bungkus yang menarik. Naskah drama merupakan karangan tertulis yang berisikan cerita yang menghadirkan watak pemain dalam sebuah pagelaran (ASMANIAH). Konflik merupakan kejadian yang tergolong penting karena berupa peristiwa fungsional dan utama. Konflik merupakan 
unsur yang esensial dalam pengambangan plot sebuah teks fiksi.konflik adalah suatu hal yang melekat pada tokoh pada sifat dan kepribadian tokoh dalam komunikasi dengan pengelohan konstruktif (Yustarini, Suhita, and Firmansyah)

Konflik dapat digambarkan melalui alur cerita dan tokoh-tokoh yang berada di dalamnya. Sebagai gejala kejiwaan psikologi pada karya sastra yang direfleksikan lewat perilaku tokohnya (Setyorini). Konflik yang sangat kental biasanya tercipta pada tokoh utama atau tokoh protagonis. Protagonis selalu menjadi tokoh yang sentral dalam cerita.

Naskah drama Nyanyian Angsa Karya Anton Chekov merupakan naskah drama yang memiliki konfik batin sangat kuat, terutama pada tokoh Vasili Svietlovidoff yang merasakan kesunyian jiwa seorang yang kesepian. Aktor kawakan yang frustrasi akan kenyataan bahwa keterasingan kesenian yang didapat justru di tengah riuh tepukan penonton. Naskah tersebut memiliki latar tempat yang sudah dijelaskan pada keterangan naskah, yaitu di sebuah gedung pertunjukan.

Dalam naskah drama Nyanyian Angsa karya Anton Chekov selaku penulis mengekspresikannya melalui keterpurukan dan keputusasaan tokoh utama karena keterasinganya di dalam dunia seni pertunjukan, sehingga para pembaca akan mendapatkan peristiwa yang bersuasana kontemplatif tentang konflik kejiwaan pada tokoh utamanya, yaitu Vasili Svietlovidoff selalu memiliki konfik batin tentang persoalan eksistensi diri.

Berdasarkan latar belakang dan identifikasi masalah yang telah dikemukakan di atas, pembahasan masalah ini perlu dibatasi agar tidak meluas, maka pembahasan masalah lebih terfokus pada bagaimana konflik batin $I d><$ Ego, Id $><$ Superego, dan Eros $><$ Thanatos pada tokoh Svietlovidoff yang terdapat dalam naskah drama Nyanyian Angsa karya Anton Chekov?

Berdasarkan pembatasan masalah yang telah dikemukakan di atas, masalah dalam penelitian ini dapat dirumuskan sebagai berikut. Sebuah karya sastra tidak mungkin tidak memiliki konflik. Begitu pun dengan tokoh Svietlovidoff pada naskah Nyanyian Angsa Karya Anton Chekov. Konflik batin dalam pikirannya sudah sangat jelas tersampaikan tanpa perlu bertanya lebih dalam lagi. Oleh karena itu, konflik yang diangkat adalah konflik batin dari keadaan psikologis (Id, Ego, Superego, Eros dan Thanatos).

Adapun tujuan yang ingin dicapai melalui penelitian ini adalah untuk mengetahui dan mendeskripsikan data empiris tentang kandungan konflik batin yang terdapat dalam sebuah cerita, unsur konflik ketegangan dan pertentangan yang terjadi dalam cerita, keadaan psikologi pada tokoh Svietlovidoff, dan mengetahui pertentangan batin Svietlovidoff yang didasari oleh pertentangan eksistensi diri.

\section{Metode / Method (12pt)}

\section{Fokus}

Penelitian ini difokuskan pada karya sastra yaitu naskah drama yang berjudul naskah drama Nyanyian Angsa karya Anton Chekov, di dalam naskah tersebut, penulis fokus pada analisis konflik batin tokoh utama dalam naskah drama Nyanyian Angsa karya Anton Chekov.

\section{Subfokus}

Pada naskah drama yang berjudul naskah drama Nyanyian Angsa karya Anton Chekov ini terdiri dari 10 halaman. Maka subfokus yang dianalisis oleh penulis yaitu unsur Id $><$ Ego, Id $><$ Superego, dan Eros $><$ Thanatos tokoh utama dalam naskah drama Nyanyian Angsa karya Anton Chekov.

\section{IInstrumen}

Instrumen penelitian dilakukan dengan mengembangkan penyusunan catatan intrinsik terhadap teks sastra yang diteliti. Berdasarkan pada bahan material berupa teks sastra, Instrumen penelitian adalah alat yang merujuk pada sarana pengumpulan data (Ramadania, Saberan, and Jamilah),maka instrumen penelitian difokuskan pada penetapan unsur konflik batin pada tokoh utama melalui unsur kejiwaan atau psikologis antara unsur id $><$ ego, id $><$ superego, dan eros $><$ thanatos. Untuk memudahkan pengumpulan data, instrumen yang digunakan adalah tabel analisis data tentang unsur 
konflik batin dalam naskah drama drama Nyanyian Angsa karya Anton Chekov sebagaimana contoh di bawah ini:

Tabel 1

Matrix Unsur Konflik batin Tokoh Utama dalam Naskah Drama

"Nyanyian Angsa"Karya Anton Chekov dan

Implikasinya terhadap Pengajaran Sastra

\begin{tabular}{|c|c|c|c|c|}
\hline \multirow[b]{2}{*}{ No. } & \multirow[b]{2}{*}{ Adegan Cerita } & \multicolumn{3}{|c|}{$\begin{array}{l}\text { Unsur Konflik } \\
\text { batin }\end{array}$} \\
\hline & & 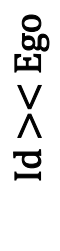 & 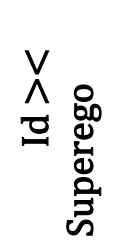 & 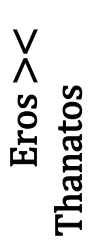 \\
\hline
\end{tabular}

Tabel 2

Persentase Unsur Konflik batin Tokoh Utama dalam Naskah Drama

"Nyanyian Angsa"Karya Anton Chekov dan

Implikasinya terhadap Pengajaran Sastra

\begin{tabular}{|c|c|c|c|}
\hline 0 & Konflik Batin & $\begin{array}{l}\text { Jumlah } \\
\text { Adegan }\end{array}$ & $\begin{array}{l}\text { Persent } \\
\text { ase }\end{array}$ \\
\hline & Id $><$ Ego & & \\
\hline & $\begin{array}{c}\text { Id }>< \\
\text { Superego }\end{array}$ & & \\
\hline & $\begin{array}{l}\text { Eros }>< \\
\text { Thanatos }\end{array}$ & & \\
\hline & Jumlah & & \\
\hline
\end{tabular}

\section{Hasil dan Diskusi / Result and Discussions}

Berdasarkan deskripsi informasi penelitian di atas, naskah drama Nyanyian Angsa karya Anton Chekov ini mengandung unsur konflik batin yang terdiri dari $I d\rangle\langle$ ego, Id $\rangle\langle$ Superego dan Eros $><$ Thanatos. Hasil temuan penelitian sebagai berikut:

1. Analisis Konflik Batin $I d><$ ego

Temuan unsur konflik batin yang terdapat dalam kutipan ini, menggambarkan $I d><$ ego yang dialami oleh Svietlovidoff sebagai tokoh utama.

"Selamatlah kau pemuda gaek! (memanggil) Yeghorka! Petruskha! Di mana engkau setan, Petruska? Kedua bajingan itu tentulah sudah tidur, dan meskipun gempa tak akan bisa membangunkan mereka sekarang! Yekhorka (mengambil kursi polos, lalu duduk setelah meletakkanlilin di atas lantai) tak ada suara! Hanya gema yang menyahutku. Aku beri yegorkha dan petruskha persen setiap hari dan mereka telah hembus dan mungkin sekali telah mengunci gedung teater ini.(menggoyang-goyangkan kepalanya)." (hal 1) 
Dari kutipan di atas mengambarkan keadaan jiwa Svietlovidoff yang mengharapkan hadirnya seorang teman untuk mememanainya di dalam gedung pertunjukan ketika malam hari namun, teman yang diharapakan tak kunjung tiba, maka hanya kesunyian dan sepi yang menemaninya saat ia sedang sendiri.

"Sungguh gila! Tolol sekali! Si jahanam yang malang dan gaek ini telah mabuk lagi dan tidak tahu apa sebenarnya yang dia Tuhankan! Ugh kepalaku remuk, seluruh tubuhku menggeletar dan aku merasa dingin serta gelap bagaikan dalam kolong bawah tanah. Bahkan jika aku tidk lupa hancurnya kesehatanku,

seharusnyalah aku ingat umurku.Betul-betul si gaek yang tolol aku ini. Yah! Umurku yang telah tua, tak ada gunanya lagi.dan aku yang berlaku dengan tolol, pongah, dan pura-pura muda padahal hidupku sekarang telah usai."(hal 1dan 2)

Dari kutipan di atas mengambarkan keadaan jiwa Svietlovidoff yang mengharapkan dirinya seperti masih muda, namun kenyataan berkata lain bahwa dirinya kini sudah tua.

"Menggunturlah sesuka hatimu! Muntahkan kabar!Luncurkanlah hujan! Bukan cuma hujan. Angin, kilat, api adalah putri-putrimu. Aku bukan menuntutmu, kau anasiranasir, dengan kejahatan aku tak pernah beri kau kerajaan, kunamakan kau anak-anak nada Ah! Sungguh mampu dan berbakat kau! Dan, aku memang artis ulung! Selanjutnya kini, iniloah sesuatu lagi semacam tadi, untuk mengembalikan masa mudaku lagi." (hal 7)

Dari kutipan di atas mengambarkan keadaan jiwa Svietlovidoff yang mengharapkan kemudaanya kembali lagi namun kenyataanya sekarang ia sudah tua dan ia harus menerima bahwa keinginanya tidak sesuai dengan realita yang terjadi.

"Aku sungguh-sungguh tak mengerti itu."(hal 7)

Dari kutipan diatas yang menggambarkan bahwa Svietlovidoff keinginanya memaksa orang lain untuk menjadi apa yang dia inginkan namun, kenyataanya orang lain tidak bisa menjadi apa yang dia inginkan.

"Kuharap kau." (hal 8)

Dari kutipan di atas menggambarkan bahwa Svietlovidoff terus menyimpan harapan pada orang lain. Dia tidak pernah lelah untuk membangun harapan-harapan itu setinggi mungkin, meski nantinya dia hanya akan mendapati kekecewaan, karena kenyataan tidak sesuai dengan apa yang dia inginkan

"Aku mohon padamu!." (hal 8)

Dari kutipan di atas menggambarkan bahwa Svietlovidoff tidak pernah lelah untuk berharap,sampai dia memohon agar keinginanya dapat terwujud.

"Inimudah saja seperti berbaring-baring : tutuplah lubang-lubang itudengan jari, keluarkan napas dari mulutmu, dan nanti akan terdengar musik yang amat merdu. Perhatikan, itu penutupnya."(hal 8)

Dari kutipan di atas menggambarkan bahwa Svietlovidoff mencoba menyakinkan orang lain bahwa apa yang dia inginkan tidak begitu sulit namun kenyataan tidak seperti yang ia harapkan.

\section{Analisis konflik batin Id $><$ Superego}

Temuan unsur konflik batin yang terdapat dalam kutipan ini, menggambarkan $I d\rangle\langle$ superego yang dialami oleh Svietlovidoff sebagai tokoh utama.

"Aku semestinya diberi minuman, aku seorang tua. Aku tidak akan hidup lebih lama lagi. pada usia 68 orang pergi ke tempat beribadah, dan bersiap-siap untuk kematian. Tetapi aku di sini. Ya tuhan! Anak yatim tua ini mabuk dalam pakaian tololnya.Aku tidak pantas lagi kelihatan begini." (hal 2)

Dari kutipan di atas menggambarkan bahwa Svietlovidoff menginginkan minuman untuk membuatnya bahagia, padahal seharusnya ketia ia menginginkan kebahagiaan bukanlah dari minuman melainkan mendeaktkan kepada sang pencipta.

"Aku tak mau pulang.Aku tak punya rumah. Tidak! Tidak! Tidak!” (hal 4) 
Dari kutipan di atas menggambarkan bahwa Svietlovidoff tidak mau pulang karna ia tak punya rumah tapi, seharusnya ia berpikir bahwa rumah adalah kebutuhan utama untuk hidup karna itu manusia harus berpulang pada pada hakikat dasarnya sebagai manusia.

"Aku tak mau kesana, aku tak mau! Aku cuma sendirian di sana. Aku tak punya keluarga. Nikituskha! Tak punya istri, tak punya anak.Aku seperti angin yang berhembus melintasi padang-padang yang sepi. Aku akan mati dan tak seorangpun akan mengikuti. "Sungguh mengerikan kesendirian ini.Tak ada yang membahagiakanku, tak ada yang mengasihiku." (hal 4)

Dari kutipan di atas menggambarkan bahwa Svietlovidoff mengalami kesepian karna keinginanya tidak sesuai dengan norma yang ada di dunianya.

"Namun, malam ini ketika aku terbangun kulihat kebelakang. Di sana, di sampingku terbentanglah waktu 68 tahun. Barulah aku menyadari betapa lamannya itu sudah. Dan, semua itu telah berlalu... (tersedu-sedu)...semuanya telah berlalu." (hal 6)

Dari kutipan di atas menggambarkan bahwa Svietlovidoff menginginkan hidupnya di dunia seni pertunjukan dilakukan secara total namun, ia menyadari bahwa apa yang dilakukanya selama ini sia-sia dan buang-buang waktu.

\section{Analisis konflik batin Eros $><$ Thanatos}

Temuan unsur konflik batin yang terdapat dalam kutipan ini, menggambarkan $I d\rangle<$ superego yang dialami oleh Svietlovidoffsebagai tokoh utama.

"Kuciumi juga tanganku yang telah enampuluh depalan tahun berlalu dan tak mungkin kulihat kembali.Aku kosongkan botol itu.Hanya tinggal beberapa tetes lagi di dasar, itupun cuma kerak-kerak.Ya, ya demikianlah halnya, Vasili, pemuda gaek. Waktu telah tiba bagimu untuk meltih peranan sebagai orang mati, suka atau tidak.Kematian kini sedang diperjalanan menujuтu (melotot ke atas). Aneh sekali, meskipun aku telah berada di pentas 40 tahun selama ini, baru kali pertama inilah aku menyaksikan gedung teater ini malam hari, setelah lampu-lampu dipadamkan. Untuk kali pertama! (berjalan bangkit ke arah lampu kaki) alangkah gelapnya di sini. Aku tak dapat melihat apa-apa. Oh ya, aku dapat melihat lubang sipembisik dan mejanya, terbaring di dalam liang yang gelap, hitam tak berdasar, macam kuburan dimana maut mungkin sedang bersembunyi." (hal 2)

Dari kutipan di atas menggambarkan tokoh utama Svietlovidoff mengalami kesedihan, karena penyesalan akan apa yang telah ia lakukakn selama ini hanyalah sia-sia. Hal tersebut membuatnya putus asa akan hidup sehingga kematian seperti sudah mendekatinya.

"Ah! Nikituskha? Cobalah pikir, mereka menyeruku 16 kali. Mereka memberiku tiga bungkus bunga dan banyak lagi benda-benda yang lain. Antusias mereka sudah melonjaklonjak.Namun tiada sebuah hatipun datang setelah pementasan selesai, untuk membangunkan orang tua yang malang ini dan membawanya pulang ke rumah. Dan aku, akulah... orang tua itu Nikituskha! Usiaku telah 68,sakit-sakitan lagi, dan aku tak punya harapan lagi untuk hidup. (Jatuh memeluk leher IVANITCH dan menangis). Jangan pergi jauh NIKITUSKHA! Aku sudah uzur, tak ada harapan lagi, dan kurasa inilah saatnya aku mati. Oh ini sangat mengerikan! Mengerikan sekali!" (hal 3)

Dari kutipan di atas dapat digambarkan bahwa tokoh utama Svietlovidoff mengalami konflik batin karena kebahagian yang dirasakannya mulai sirna ketika ia mengingat antusias penonton pada waktu ia masih muda dan gagah begitu banyak namun, ketika ia sudah tua dan tidak gagah lagi antusias penonton sirna.

"Penonton sudah pulang.Mereka semua sudah tidur dan melupakan si badut tuanya.Tidak seorangpun membutuhkan aku, tak ada yang mencintaiku." (hal 4)

Dari kutipan di atas dapat digambarkan, tokoh utama Svietlovidoff mengalami sebuah kehilangan, karenaia kembali dihadapkan pada ketiadaan penonton yang peduli kepadanya pada saat ini.

"Tetapi aku seorang laki-laki dan masih hidup segar. Darah masih terus mengalir dalam nadiku, darah warisan bangsawan. Aku seorang Aristokrat Nikithuskha! Aku telah mengabdi dalam ketentaraan dibagian artileri sebelum jatuh aku jatuh hina.Betapa gagahnya aku sewaktu muda. Tampan gagah dan berani! Kemanakah itu semua pergi?Apa jadinya itu semua dimasa tua? Tentulah ada liang yang telah menelan itu 
semua! Aku mengenang itu semua sekarang.Telah 45 tahun hidupku tenggelam disitu. Hidup apa itu Nikituskha?. Aku dapat melihatnya dengan jelas seperti melihat wajahmu: remaja yang riang , bersemangat, gairah pujaan wanita. Wanita Nikituskha!" (hal 4)

Dari kutipan di atas menggambarkan bahwa tokoh utama Svietlovidoff mengalami pertentangan batin.Ia mulai merasa putus asa karena apa yang ia punya saat muda tidak bisa menjamin dirinya bahagia ketika ia sudah tua

"Ketika baru-baru aku naik ke pentas, semasih gairah remaja bergejolak, aku ingat seorang wanita yang jatuh cinta karena aktingku. Dia sangat cantik, tinggi semampai, muda, suci, tak bercela, berseri-seri laksana fajar musim panas.Semuanya dapat tembus menyinari kegelapan malam. "Masih kuingat sekali ketika aku berdiri di depannya seperti sekarang aku berdiri didepanmu.Dia kelihatan begitu mencintaiku, tidak seperti kenyataan kemudian. Berkatalah ia kepadaku supaya memandang dengan pandangan demikian! Pandangan yang tidak dapat kulupakan, tidak bahkan sampai kekubur seklipun. Begitu kasih, begitu lembut, begitu dalam, begitu bersinar ceria! "Dengan sangat riang mabuk kepayang, aku berlutut di hadapannya. Lalu aku mohon demi kebahagiaan, dan berkatalah ia: " tinggalkan pentas". Kau mengerti?Dia dapat mencintai akting. Tetapi, buat mengawininya tidak! Aku sedang berlakon pada suatu ketika.Ya, aku ingat, aku berperan sebagai badut yang tolol. Setelah berlakon aku merasa mataku jadi terbuka karena melihat apa yang pernah kuanggap pemujaan kepada seni begitu suci, sebenarnya adalah khayalan dan impian kosong belaka. Bahwa aku adalah badut yang tolol dan menjadi permainan yang asing dan sia-sia.

"Akhirnya aku mengerti tentang penonton.Sejak saat itu aku tak percaya lagi pada tepukan tepukan mereka, atau pada bungkusan bunga mereka atau pada ketertarikan mereka. Ya, Nikituskha!orang memuja aku, membeli gambarku, tetapi aku tetap asing bagi mereka. Mereka memburu-mburu supaya dapat bertemu dengan aku tetapi melarang adik perempuan atau putrinya untuk kawin denganku, seorang yang hina dina. Tidak! Aku tak yakin lagi kepada mereka. (terhenyak dalam kursi polos) Tak yakin lagi kepada mereka." (hal 5)

Dari kutipan di atas menggambarkan tokoh utama Svietlovidoff dihadapkan pada situasi yang begitu sulit yaitu saat rona kebahagiaan di tengah eksistensinya sebagai seorang aktor hebat tidak bisa menjamin kehadiran wanita untuk mencintainya. Justru yang ia dapatkan hanyalah sebuah kehilangan

"Ketika aku telah mengetahui segalanya dan pengetahuan itu telah dibeli tunai, Nikituskha! Setelah itu...jika gadis itu...nah, kumulailah penggambaran tanpa tujuan hidup dari hari kehari, tanpa tujuan apa-apa.Akupun mengambil peranan pelawak murahan.Membiarkan diriku hancur.Oh, mestinya aku dulu adalah seorang artis yang besar namun perlahan-lahan aku buang jauh-jauh bakatku dan memainkan banyolanbanyolan tolol, kehilangan pegangan, kehilangan kekuatan ekspresi diri.Lalu, akhirnya hanya menjadi seorang banci

Marry Andrew dari pada seorang laki-laki. Aku telah ditelan seluruhnya kedalam liang besar yang gelap." (hal 6)

Dari kutipan di atas menggambarkan tokoh utama Svietlovidoff yang mengungkapkan keluh kesahnya terhadap apa yang telah ia capai saat muda sebagai seorang aktor hebat mulai ia tinggalkan kemudian ia lebih memilih untuk menjadi peran badut yang justru tidak membantunya.

"Tetapi, betapa jeniusnya aku. Aku tidak bisa membayangkan kemampuanku, betapa fasih, bagaimana menariknya aku, betapa peka, dan betapa hebat tali senar (menepuk-nepuk dada) menggetar di dalam dada ini. Sungguh berdebar perasaanku memikirkannya!

Dengarlah sekarang! Tunggu! Bisr sku tsrik napas dulu. Yah, sekarang dengarkanlah ini: ; Berlindung darah ivan kini kembali

Terkipas dari bibirku pemberontakan berkobar Akulah Dimitri yang buta! Di dalam kobaran apiu Boris akan musnah diatas tahta yang kutuntut Cukup! Pewaris tsar tak tampak lagi Berlutut ke sana ke ratu Polanbdia yang congkak" (dari : Boris Gonudof, karya Pushkin) 
Jelekkah itu, ha? (cepat) Tunggu! Nah ini sesuatu dari Raja Lear. Langit gelap, kelihatan hujan turun deras, guruh mengguntur, kilat ... zzz zzz zzz ... menerangi seluruh permukaan langit, dan kemudian dengarkanlah : ;Tiuplah angin, hancurkan pelipismu! Amuk! Tiupkan! Sehingga kau basahi puncak menara kami, tenggelamkanlah ayam-ayam Kau berlekang pikiran yang pasti membakar Patung disambar petir Hanguskan kepalaku yang ubanan! Dan kau segala guruh Yang menggelegar pukul ratakan bentuk dunia yang gemuk! Hancurkan kesuburan dunia, segala kecambah leburkan sekali Itulah yang membuat orang tak bersyukur!

(Tak sabar) Sekarang, peran si tolol. (Menghentakkan kakinya) Lekas ambil peran si tolol! Cepat! Aku tidak bisa menunggu."

(hal 6 dan 7)

Dari kutipan di atas menggambarkan tokoh utama Svietlovidoff yang telah pasrah dengan semua keadaan yang kini menghampirinya. Ia merasa sudah tak bisa lagi memikirkan semua yang menimpanya, hingga ia memasrahkannya, meski tak tau apa yang akan terjadi nantinya.

"Mengapa? Ingatlah betapa tak berguna yang kau lakukan untukku, kau harus nampak paham akan istirahatku, kau harus bisa menangkap hakikat dari kegaibanku, kau harus mendengar dari catatanku yang mula-mula, sehingga puncak pedomanku. Dan disitulah terdapat pelbagai musik, suara yang indah didalam alat yang kecil ini, meskipun kau tidak bisa meniupnya sehingga berbunyi. Astaga! Kau pikir aku hanya mudah meniup suling ini saja?Sebutlah alat istrument mana yang kau kehendaki, meskipun kau tak yakin kepadaku. Kau memang tak bisa melakukannya untukku...!" (TERTAWA DAN BERTEPUK) Hebat! Hebat sekali! Dimanakah setan yang bersarang didalam usia tua itu? Aku bukan orang tua, semuanya itu omong kosong. Arus tenaga masih mengalir dalam diriku, inilah hidup, gairah dan muda! Usia muda dan jenius tentulah tidak berdampingan bersama-sama. Kau nampak membisu saja, Nikitushka.Tunggulah sejenak sampai kekuasaanku pulih kembali. Oh, rumah! Sekarang perhatikan! Pernahkan kau mendengar begitu lembut seperti musik?Pelan-pelan. "Bulan telah lenyap, tiada lagi cahaya, mendampingi gugusan bintang kesepian yang merapat pucat.Dicakrawala, ada yang tiba-tiba bercahaya bunga putih bersih ditengah-tengah lembah bunga mawar disusupi kunang-kunang, yang cahayanya suram berkedip-kedip, bagai harapan yang enggan menjelma." (SUARA PINTU-PINTU DIBUKA TERDENGAR) Apakah itu?" (hal 8 dan 9)

Dari kutipan di atas menggambarkan tokoh utama Svietlovidoff yang mengalami kesepian dalam kehidupannya sehari-hari, saat yang diharapkan tak terwujud, maka kebahagiaannya pun di gantikan menjadi kesepian yang menemaninya kini.

"(Memanggil, berpaling ke arah suara-suara tadi) Kasihanilah anak-anak. (Kepada IVANITCH) Ayolah kita pergi tukar pakaian.Aku bukan orang tua. Semua itu tolol, omong kosong! (Tertawa gembira)Apa yang kau tangisi? Ini bukan ... kemauan! Ya, ya, segalanya ini bukan kemauan! Mari, mari orang tua, jangsan terbeliak bigitu! Apa sebab kau terbeliak begitu? Ya, ya, (memeluk sambil menangis) Jangan menangis! Di mana ada seni dan jenius di situ pasti tidak ada segala ketentuan, kesepian, atau penyakitan ... hanya kematian itu yang semakin dekat. (Tersedu-sedu)Tidak! Tidak, Nikitushka!" (hal 9)

Dari kutipan di atas menggambarkan tokoh utama Svietlovidoff telah berputus asa atas semua yang telah menimpanya.

"Segalanya itu telah berlalu dari kita sekarang! Betapa jeniusnya aku!

Aku seperti uap lemin, botol pecah. Dan, kau, kau adalah tikus tua gedung teater ... pembisik, ayolah!

Mereka pergi) Aku bukanlah jenius.Aku hanyalah cocok disamakan dengan promter.Bahkan, untuk itupun aku terlalu tua. Ya ... kau ingatkan baris-baris ini dari Othelo, Nikitushka!

Selamat tinggal kenangan damai!

Maha perang

Yang mengalahkan angin unggul!

Oh, selamat tinggal! 


\section{Selamat tinggal ringkik kuda, dan sangkakala terompet \\ Pukulan genderang bersemangat \\ Suling yang menembus pendengaran"}

Dari kutipan di atas menggambarkan tokoh utama Svietlovidoff yang mengalami sebuah konflik yang amat dalam sehingga membuatnya terpaksa kalah dalam kesepian yang telah lama menjeratnya.

Tabel 4.1
Matrix Unsur Konflik batin Tokoh Utama dalam Naskah Drama "Nyanyian Angsa" Karya Anton Chekov dan Implikasinya terhadap Pengajaran Sastra

\begin{tabular}{|c|c|c|c|c|}
\hline \multirow[b]{2}{*}{ NO } & \multirow[b]{2}{*}{ Adegan } & \multicolumn{3}{|c|}{ Konflik Batin } \\
\hline & & $\hat{0}$ & 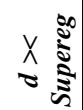 & 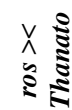 \\
\hline 1. & $\begin{array}{l}\text { "Selamatlah kau pemuda gaek! (memanggil) Yeghorka! } \\
\text { Petruskha! Di mana engkau setan, Petruska? Kedua bajingan itu tentulah } \\
\text { sudah tidur, dan meskipun gempa tak akan bisa membangunkan mereka } \\
\text { sekarang!" "petruskha persen setiap hari dan mereka telah hembus dan } \\
\text { mungkin sekali telah mengunci gedung teater ini." (hal 1) }\end{array}$ & & & \\
\hline 2. & $\begin{array}{l}\text { "Sungguh gila! Tolol sekali! Si jahanam yang malang dan gaek } \\
\text { ini telah mabuk lagi dan tidak tahu apa sebenarnya yang dia Tuhankan! Ugh } \\
\text { kepalaku remuk, seluruh tubuhku menggeletar dan aku merasa dingin serta } \\
\text { gelap bagaikan dalam kolong bawah tanah. Bahkan jika aku tidk lupa } \\
\text { hancurnya kesehatanku, seharusnyalah aku ingat umurku. Betul-betul si } \\
\text { gaek yang tolol aku ini. Yah! Umurku yang telah tua, tak ada gunanya lagi. } \\
\text { dan aku yang berlaku dengan tolol, pongah, dan pura-pura muda padahal } \\
\text { hidupku sekarang telah usai." (hal } 1 \text { dan 2) }\end{array}$ & $\sqrt{ }$ & & \\
\hline 3. & $\begin{array}{l}\text { "Kuciumi juga tanganku yang telah enampuluh depalan tahun } \\
\text { berlalu dan tak mungkin kulihat kembali. Aku kosongkan botol itu. Hanya } \\
\text { tinggal beberapa tetes lagi di dasar, itupun cuma kerak-kerak. Ya, ya } \\
\text { demikianlah halnya, Vasili, pemuda gaek. Waktu telah tiba bagimu untuk } \\
\text { meltih peranan sebagai orang mati, suka atau tidak. Kematian kini sedang } \\
\text { diperjalanan menujumu (melotot ke atas). Aneh sekali, meskipun aku telah } \\
\text { berada di pentas } 40 \text { tahun selama ini, baru kali pertama inilah aku } \\
\text { menyaksikan gedung teater ini malam hari, setelah lampu-lampu } \\
\text { dipadamkan. Untuk kali pertama! (berjalan bangkit ke arah lampu kaki) } \\
\text { alangkah gelapnya di sini. Aku tak dapat melihat apa-apa. Oh ya, aku dapat } \\
\text { melihat lubang sipembisik dan mejanya, terbaring di dalam liang yang } \\
\text { gelap, hitam tak berdasar, macam kuburan dimana maut mungkin sedang } \\
\text { bersembunyi." (hal 2) }\end{array}$ & & & $\sqrt{ }$ \\
\hline 4. & $\begin{array}{l}\text { Aku semestinya diberi minuman, aku seorang tua. Aku tidak } \\
\text { akan hidup lebih lama lagi. pada usia } 68 \text { orang pergi ke tempat beribadah, } \\
\text { dan bersiap-siap untuk kematian. Tetapi aku di sini. Ya tuhan! Anak yatim } \\
\text { tua ini mabuk dalam pakaian tololnya. Aku tidak pantas lagi kelihatan } \\
\text { begini.(hal 2) }\end{array}$ & & $\sqrt{ }$ & \\
\hline 5. & $\begin{array}{l}\text { "Ah! Nikituskha? Cobalah pikir, mereka menyeruku } 16 \text { kali. } \\
\text { Mereka memberiku tiga bungkus bunga dan banyak lagi benda-benda yang } \\
\text { lain. Antusias mereka sudah melonjak-lonjak.Namun tiada sebuah hatipun } \\
\text { datang setelah pementasan selesai, untuk membangunkan orang tua yang } \\
\text { malang ini dan membawanya pulang ke rumah. Dan aku, akulah... orang } \\
\text { tua itu Nikituskha! Usiaku telah } 68 \text {,sakit-sakitan lagi, dan aku tak punya } \\
\text { harapan lagi untuk hidup. (Jatuh memeluk leher IVANITCH dan } \\
\text { menangis). Jangan pergi jauh NIKITUSKHA! Aku sudah uzur, tak ada } \\
\text { harapan lagi, dan kurasa inilah saatnya aku mati. Oh ini sangat mengerikan! } \\
\text { Mengerikan sekali!" (hal 3) }\end{array}$ & & & $\sqrt{ }$ \\
\hline
\end{tabular}




\begin{tabular}{|c|c|c|c|}
\hline 6. & $\begin{array}{l}\text { "Aku tak mau pulang. Aku tak punya rumah. Tidak! Tidak! } \\
\text { Tidak!" (hal 4) }\end{array}$ & & \\
\hline 7. & $\begin{array}{l}\text { "Aku tak mau kesana, aku tak mau! Aku cuma sendirian di sana. } \\
\text { Aku tak punya keluarga. Nikituskha! Tak punya istri, tak punya anak. Aku } \\
\text { seperti angin yang berhembus melintasi padang-padang yang sepi. Aku } \\
\text { akan mati dan tak seorangpun akan mengikuti. "Sungguh mengerikan } \\
\text { kesendirian ini.Tak ada yang membahagiakanku, tak ada yang } \\
\text { mengasihiku." } \\
\text { (hal 4) }\end{array}$ & $\sqrt{ }$ & \\
\hline 8. & $\begin{array}{l}\text { "Penonton sudah pulang. Mereka semua sudah tidur dan } \\
\text { melupakan si badut tuanya. Tidak seorangpun membutuhkan aku, tak ada } \\
\text { yang mencintaiku." (hal 4) }\end{array}$ & & $\sqrt{ }$ \\
\hline 9. & $\begin{array}{l}\text { "Tetapi aku seorang laki-laki dan masih hidup segar. Darah } \\
\text { masih terus mengalir dalam nadiku, darah warisan bangsawan. Aku } \\
\text { seorang Aristokrat Nikithuskha! Aku telah mengabdi dalam ketentaraan } \\
\text { dibagian artileri sebelum jatuh aku jatuh hina. Betapa gagahnya aku } \\
\text { sewaktu muda. Tampan gagah dan berani! Kemanakah itu semua pergi? } \\
\text { Apa jadinya itu semua dimasa tua? Tentulah ada liang yang telah menelan } \\
\text { itu semua! Aku mengenang itu semua sekarang. } \\
\text { Telah } 45 \text { tahun hidupku tenggelam disitu. Hidup apa itu } \\
\text { Nikituskha?. Aku dapat melihatnya dengan jelas seperti melihat wajahmu : } \\
\text { remaja yang riang , bersemangat, gairah pujaan wanita. Wanita } \\
\text { Nikituskha!" (hal 4) }\end{array}$ & & $\sqrt{ }$ \\
\hline 10. & $\begin{array}{l}\text { "Ketika baru-baru aku naik ke pentas, semasih gairah remaja } \\
\text { bergejolak, aku ingat seorang wanita yang jatuh cinta karena aktingku. Dia } \\
\text { sangat cantik, tinggi semampai, muda, suci, tak bercela, berseri-seri laksana } \\
\text { fajar musim panas. Semuanya dapat tembus menyinari kegelapan malam. } \\
\text { "Masih kuingat sekali ketika aku berdiri di depannya seperti sekarang aku } \\
\text { berdiri didepanmu.Dia kelihatan begitu mencintaiku, tidak seperti } \\
\text { kenyataan kemudian. Berkatalah ia kepadaku supaya memandang dengan } \\
\text { pandangan demikian! Pandangan yang tidak dapat kulupakan, tidak bahkan } \\
\text { sampai kekubur seklipun. Begitu kasih, begitu lembut, begitu dalam, begitu } \\
\text { bersinar ceria! "Dengan sangat riang mabuk kepayang, aku berlutut di } \\
\text { hadapannya. Lalu aku mohon demi kebahagiaan, dan berkatalah ia: " } \\
\text { tinggalkan pentas". Kau mengerti? Dia dapat mencintai akting. Tetapi, buat } \\
\text { mengawininya tidak! Aku sedang berlakon pada suatu ketika. Ya, aku ingat, } \\
\text { aku berperan sebagai badut yang tolol. Setelah berlakon aku merasa mataku } \\
\text { jadi terbuka karena melihat apa yang pernah kuanggap pemujaan kepada } \\
\text { seni begitu suci, sebenarnya adalah khayalan dan impian kosong belaka. } \\
\text { Bahwa aku adalah badut yang tolol dan menjadi permainan yang asing dan } \\
\text { sia-sia. } \\
\text { "Akhirnya aku mengerti tentang penonton. Sejak saat itu aku tak } \\
\text { percaya lagi pada tepukan tepukan mereka, atau pada bungkusan bunga } \\
\text { mereka atau pada ketertarikan mereka. Ya, Nikituskha!orang memuja aku, } \\
\text { membeli gambarku, tetapi aku tetap asing bagi mereka. Mereka memburu- } \\
\text { mburu supaya dapat bertemu dengan aku tetapi melarang adik perempuan } \\
\text { atau putrinya untuk kawin denganku, seorang yang hina dina. Tidak! Aku } \\
\text { tak yakin lagi kepada mereka. (terhenyak dalam kursi polos) Tak yakin lagi } \\
\text { kepada mereka." (hal 5) }\end{array}$ & & $\sqrt{ }$ \\
\hline 11. & $\begin{array}{l}\text { "Ketika aku telah mengetahui segalanya dan pengetahuan itu } \\
\text { telah dibeli tunai, Nikituskha! Setelah itu...jika gadis itu...nah, kumulailah } \\
\text { penggambaran tanpa tujuan hidup dari hari kehari, tanpa tujuan apa-apa. } \\
\text { Akupun mengambil peranan pelawak murahan. Membiarkan diriku } \\
\text { hancur.Oh, mestinya aku dulu adalah seorang artis yang besar namun } \\
\text { perlahan-lahan aku buang jauh-jauh bakatku dan memainkan banyolan- } \\
\text { banyolan tolol, kehilangan pegangan, kehilangan kekuatan ekspresi diri. } \\
\text { Lalu, akhirnya hanya menjadi seorang banci Marry Andrew dari pada } \\
\text { seorang laki-laki. Aku telah ditelan seluruhnya kedalam liang besar yang } \\
\text { gelap." (hal 6) }\end{array}$ & & $\sqrt{ }$ \\
\hline 12. & $\begin{array}{l}\text { "Namun, malam ini ketika aku terbangun kulihat kebelakang. Di } \\
\text { sana , di sampingku terbentanglah waktu } 68 \text { tahun. Barulah aku menyadari } \\
\text { betapa lamannya itu sudah. Dan, semua itu telah berlalu... (tersedu- } \\
\text { sedu)... semuanya telah berlalu." (hal 6) }\end{array}$ & $\sqrt{ }$ & \\
\hline 13. & $\begin{array}{l}\text { "Tetapi, betapa jeniusnya aku. Aku tidak bisa membayangkan } \\
\text { kemampuanku, betapa fasih, bagaimana menariknya aku, betapa peka, dan } \\
\text { betapa hebat tali senar (menepuk-nepuk dada) menggetar di dalam dada ini. } \\
\text { Sungguh berdebar perasaanku memikirkannya! } \\
\text { Dengarlah sekarang! Tunggu! Bisr sku tsrik napas dulu. Yah, } \\
\text { sekarang dengarkanlah ini: ; Berlindung darah ivan kini kembali } \\
\text { Terkipas dari bibirku pemberontakan berkobar AkulahDimitri } \\
\text { yang buta! Di dalam kobaran apiu Boris akan musnah diatas tahta yang } \\
\text { kutuntut Cukup! Pewaris tsar tak tampak lagi Berlutut ke sana ke ratu }\end{array}$ & & $\sqrt{ }$ \\
\hline
\end{tabular}




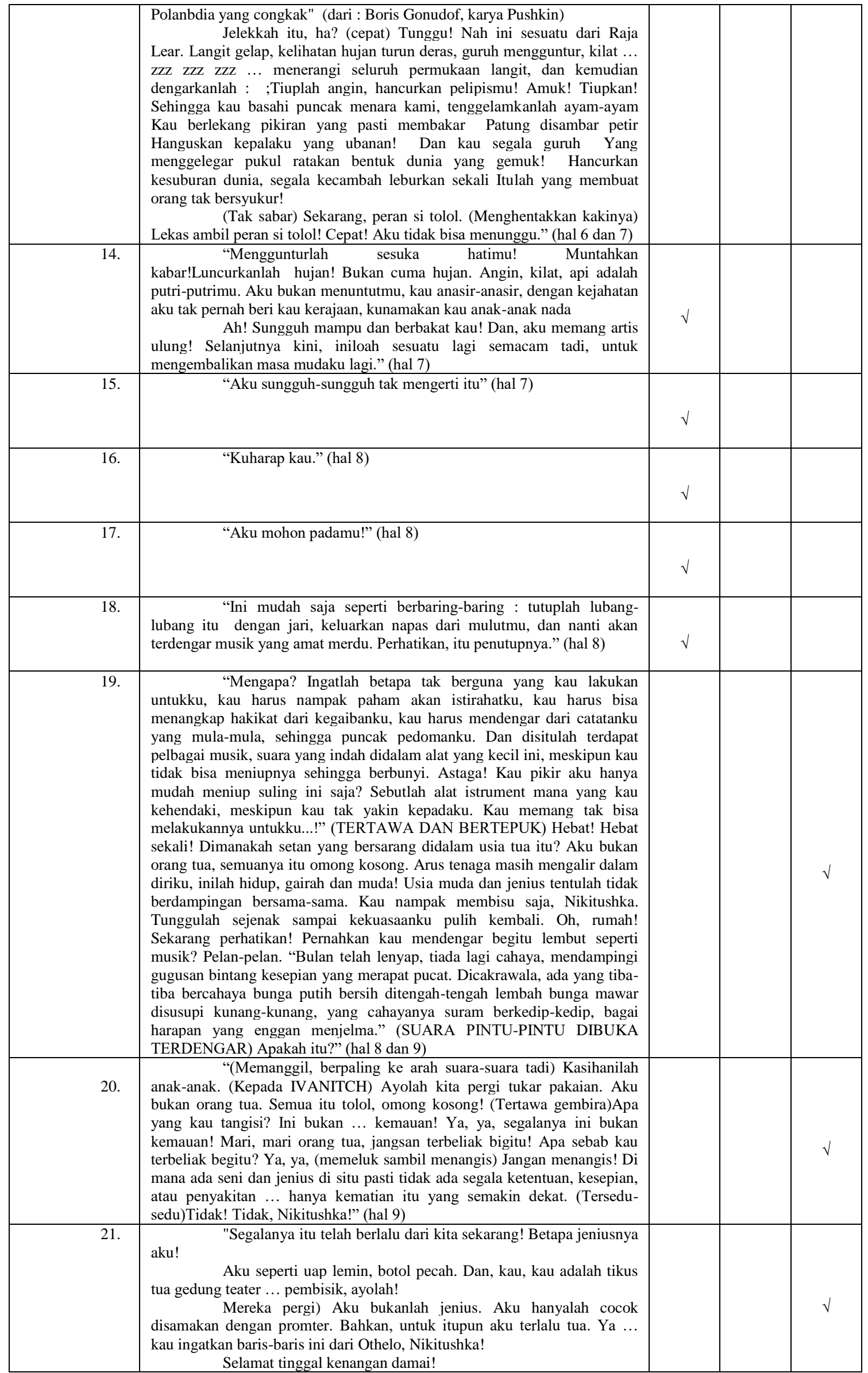




\begin{tabular}{|l|l|l|l|}
\hline & \multicolumn{1}{|l|}{$\begin{array}{l}\text { Maha perang } \\
\text { Yang mengalahkan angin unggul! } \\
\text { Oh, selamat tinggal! } \\
\text { Selamat tinggal ringkik kuda, dan sangkakala terompet } \\
\text { Pukulan genderang bersemangat } \\
\text { Suling yang menembus pendengaran" }\end{array}$} & & \\
\hline
\end{tabular}

Berdasarkan temuan penelitian di atas, dapat diperoleh persentase dan diagram lingkaranunsur konflik batin dalam naskah drama Nyanyian Angsa karya Anton Chekovdengan menggunakan unsur konflik batin sebagai berikut:

Tabel 4.2

Persentase Unsur Konflik batin Tokoh Utama dalam Naskah Drama

"Nyanyian Angsa" Karya Anton Chekov dan Implikasinya terhadap Pengajaran Sastra

\begin{tabular}{|c|l|c|c|}
\hline \multicolumn{1}{|c|}{ No } & \multicolumn{1}{|c|}{ Konflik Batin } & Jumlah Adegan & Persentase \\
\hline 1. & Id $><$ Ego & 7 & $33,3 \%$ \\
\hline 2. & Id $><$ Superego & 4 & $19 \%$ \\
\hline 3. & Eros $><$ Thanatos & 10 & $47,7 \%$ \\
\hline & Jumlah & 21 & $100 \%$ \\
\hline
\end{tabular}

Keterangan tabel perhitungan : $\frac{\text { dialog }}{\text { jumlah temuan hasil }} \times 100$
1. Id $><$ Ego
$: \frac{7}{21} \times 100=33,3 \%$
2. Id $><$ Superego
$: \frac{4}{21} \times 100=19 \%$
3. Eros $><$ Thanatos $: \frac{10}{21} \times 100=47,7 \%$

Diagram Lingkaran Unsur Konflik Batin Tokoh Utama dalam Naskah Drama Nyanyian Angsa Karya Anton Chekov dan Implikasinya terhadap Pengajaran Sastra

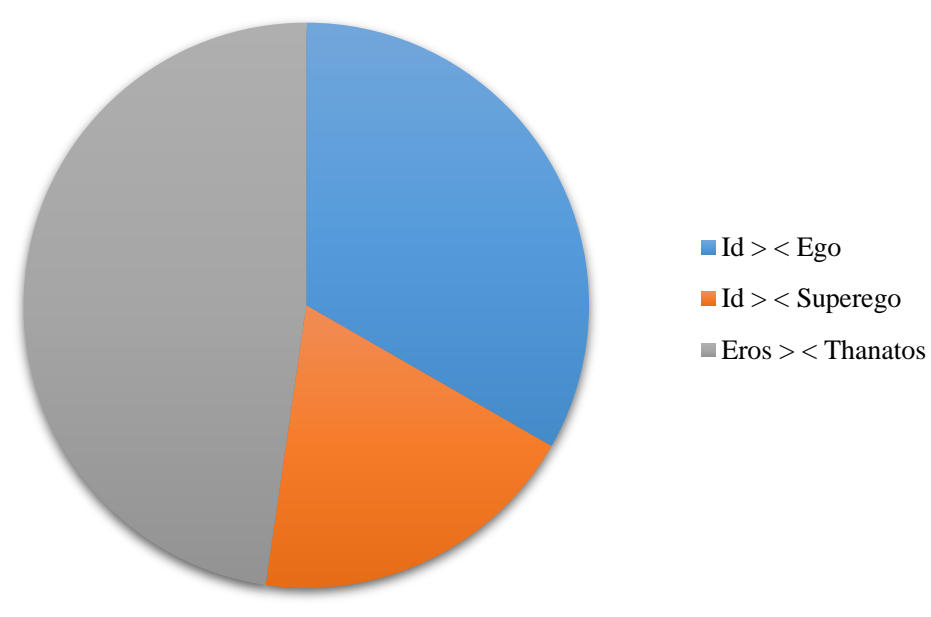


Mengacu pada tabel dan diagram komposisi konflik batin tokoh utama dalam naskah drama Nyanyian Angsa karya Anton Chekov, unsur konflik batin yang dominan adalah unsur konflik batin Eros $><$ Thanatos yang mencapai47,7 \% , dengan temuan sebanyak 10 kutipan; $I d><$ Egoyang mencapai 33,3\% dengan temuan 7 kutipan; diikuti dengan unsur konflik batin id $><$ superego yaitu mencapai $19 \%$ dengan temuan 4 kutipan.

Aspek konflik batin unsurEros $><$ Thanatos menjadi unsur yang dominan dalam penelitian ini, karena harapan yang tidak terealisasikan, kebahagiaan yang berubah menjadi sebuah kesedihan karena keinginan yang tidak dapat terpenuhi.Maka dari itu, hal inilah yang menyebabkan timbulnya konflik batin dalam diri tokoh utama.

\section{Simpulan / Conclusions}

Berdasarkan data empiris yang telah diperoleh penulis dalam penelitian mengenai konflik batin tokoh utama dalam naskah drama Nyanyian Angsa karya Anton Chekov dan Implikasinya terhadap Pengajaran Sastra, dapat ditarik simpulan. Simpulan tersebut, di antaranya:

1. Dalam penelitian yang telah dilakukan ini, terdapat unsur konflik batin yang digambarkan oleh tokoh utama. Dua Unsur konflik batin yang paling tinggi persentasenya tersebut yaitu unsur Eros $><$ Thanatos, hal ini dapat dikatakan demikian karena harapan-harapan yang tiba-tiba harus musnah dan kebahagiaan-kebahagiaan yang digantikan oleh kesedihan yang menimpa tokoh utama, Svietlovidoff, sedangkan unsur konflik batin yang kedua yaitu Id $><E g o$, sebab kecenderungan tokoh utama yang tidak dapat memenuhi hasratnya karena berbenturan dengan realitas yang ada. Satu-satunya yang menjadi penyebab, yaitu ketika keinginan yang ia miliki tidak dapat terpenuhi karena kenyataan hidup yang ia alami tidak sesuai dengan apa yang diharapkan.

2. Analisis konflik batin pada tokoh utama dalam naskah drama Nyanyian Angsa karya Anton Chekov menggambarkan konflik batin Id $><$ Ego. Alasannya yaitu dari kalimat Nyanyian Angsa dapat dideskripsikan bahwa tokoh utama dalam naskah ini menyimpan harapan, keinginan dan dambaan untuk terus hidup dalam dunia seni pertunjukan teater meskipun dalam keterpurukan. Nyanyian Angsa di sini berupa sebuah perumpamaan yang merupakan ciri khas dari seekor angsa yang ketika dipotong masih memiliki daya untuk terus berjalan meskipun ia akan mati.

3. Dalam karyanya pengarang berusaha menyampaikan pesan kepada pembaca, bahwa sebagai seorang manusia, kita harus selalu menerima apapun keputusan Tuhan dengan ikhlas dan ketika kita berproses dalam dunia seni pertunjukan teater sefokus apapun janganlah pernah lupa bahwa kita sebagai manusia memiliki tanggung jawab.

\section{Implikasi terhadap Pengajaran Sastra di Sekolah}

Adanya pembelajaran sastra di sekolah akan memiliki nilai tambah yang cukup optimal. Pembelajaran sastra di sekolah dapat melalui kajian unsur intrinsik dan ekstrinsik, yakni unsur konflik batin yang ditinjau dari dalam diri manusia tersebut atau melalui sudut pandang eksternal yaitu luar diri manusia (lingkungan) yang terdapat dalam karya sastra yaitu naskah drama yang dijadikan sebagai bagian untuk memahami kejiwaan seseorang di dalam lingkungan sekolah dan masyarakat. Adapun beberapa dampak dari implikasi pembelajaran karya sastra yaitu naskah drama bagi pihak-pihak yang terlibat yakni sebagai berikut:

1. Dampak implikasi bagi guru, seorang guru hanya mempersiapkan segala sesuatu yang dibutuhkan untuk belajar mengajar. Persiapan tersebut meliputi silabus, program rencana pelaksanaan pembelajaran, media belajar, bahan ajar, soal, dan pedoman penilaian terhadap pembelajaran sastra yaitu naskah drama. Guru dituntut dapat mengembangkan karakter pada peserta didik. Karakter yang harus dikembangkan berupa rasa ingin tahu, disiplin, jujur,teliti, mandiri, kerja keras, berpikir logis, tanggung jawab, tekun, dan kreatif. Dengan adanya persipan yang matang dari seorang guru, pembelajaran sastra yaitu naskah drama di sekolah diharapkan akan mencapai hasil yang maksimal.

2. Dampak implikasi bagi peserta didik, pserta didik harus terlibat langsung secara aktif di dalam kegiatan pembelajaran sastra yaitu naskah drama di sekolah. Peserta didik juga dituntut agar memahami isi kandungan naskah drama dengan baik. Untuk mengembangkan pembelajaran sastra 
yaitu naskah drama, peserta didik harus mengembangkan metode belajar mandiri di luar jam sekolah, misalnya mengikuti kegiatan ekstrakulikuler teater. Hal ini dimaksudkan agar kemampuan peserta didik dapat tersalurkan dengan baik.

3. Dampak implikasi bagi sekolah, dengan adanya implikasi pembelajaran sastra yaitu naskah drama, sekolah harus menentukan kebijakan yang tepat bagi pembelajaran sastra yaitu naskah drama. Pihak sekoalah harus mengubah cara pandang yang selama ini hanya terfokus pada cara guru menyampaikan materi ajar. Sekolah harus bertanggung jawab atas keberhasilan atau tidaknya pembelajaran sastra melalui naskah drama. Oleh karena itu, sekolah juga harus berperan aktif dengan mengenali dan mengembangkan karakter siswa dan pembelajaran sastra melalui naskah drama. Sekolah juga mendukung dan mengontrol kebijakan yang dilakukan oleh guru terhadap pembelajaran sastra melalui naskah drama di sekolah.

\section{Ucapan Terima Kasih / Acknowledgement}

Penulis mengucapkan terima kasih kepada beberapa jurnal yang telah dijadikan referensi dalam penulisan ini, naskah drama nyayian angsa karya Anton Chekov dan semua pihak yang terlibat dalam proses penulisan ini.

\section{Daftar Rujukan / References}

ASMANIAH, ZAINAH. "NASKAH DRAMA RAJAPATI KARANGAN AHMAD BAKRI (Kajian Struktural Dan Pragmastilistik)." LOKABASA (2015): n. pag. Web.

Permata Yanda, Diyan. "KONFLIK BATIN TOKOH ZAHRANA DALAM NOVEL CINTA SUCI ZAHRANA KARYA HABIBURRAHMAN ELSHIRAZY." Gramatika STKIP PGRI Sumatera Barat 1.1 (2015): n. pag. Web.

Ramadania, Fajarika, Riduan Saberan, and Jamilah Jamilah. "Konflik Tokoh Utama Dalam Menghadapi Ketidakadilan Gender Pada Novel Re: Karya Maman Suherhman.” STILISTIKA: Jurnal Bahasa, Sastra, dan Pengajarannya (2018): n. pag. Web.

Setyorini, Ririn. "ANALISIS KEPRIBADIAN TOKOH MARNI KAJIAN PSIKOLOGI SIGMUND FREUD DALAM NOVEL ENTROK KARYA OKKY MADASARI.” Kajian Linguistik dan Sastra (2017): n. pag. Web.

Yustarini, Rizka, Sri Suhita, and Erfi Firmansyah. "KONFLIK BATIN TOKOH UTAMA DALAM KUMPULAN CERPEN 'MATINYA SEORANG PENARI TELANJANG' KARANGAN SENO GUMIRA AJIDARMA: SUATU KAJIAN PSIKOLOGI SASTRA.” Arkhais - Jurnal Ilmu Bahasa dan Sastra Indonesia (2015): n. pag. Web. 